\title{
The Republican Senate and Regular Order
}

\author{
Carl Tobias*
}

I. INTRODUCTION...................................................................................................

II. Non-ApPEALS Court AND EXecutive Nomination AND CONFIRMATION

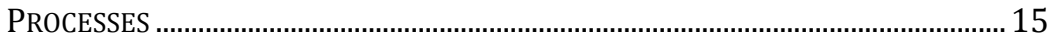

A. THE NON-APPEALS COURT PROCESSES ......................................................15

1. The Nomination Process................................................................15

2. Judiciary Committee Hearings .......................................................16

3. Judiciary Committee Discussions and Votes............................... 18

4. Floor Debates and Votes ................................................................. 19

B. EXECUTIVE BRANCH CONFIRMATION PROCESS.............................................. 24

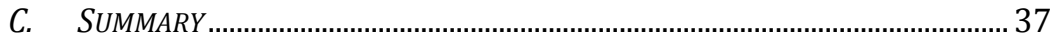

III. ApPellate Court Nomination ANd ConfiRmation Processes ........................ 27

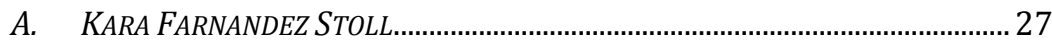

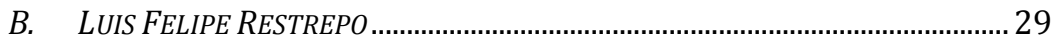

IV. The Implications of the 2015 Nomination AND CONFIRMATION

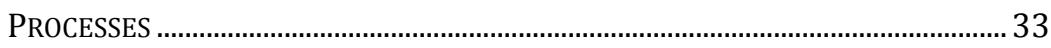

V. SUGGESTIONS FOR THE FUTURE ……………………………………………...... 34

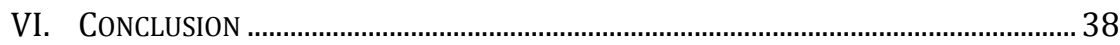

\section{INTRODUCTION}

Professors Michael Gerhardt and Michael Stein proffer numerous valuable insights on antebellum federal judicial selection, ${ }^{1}$ while Professor Jed Shugerman offers helpful perspectives respecting that specific period and elaborates on the comprehensive account carefully propounded by Professors

\footnotetext{
* Williams Chair in Law, University of Richmond. I wish to thank Peggy Sanner and Katie Lehnen for valuable ideas, Leslee Stone for excellent processing, as well as Russell Williams and the Hunton Williams Summer Endowment Fund for generous, continuing support. Remaining errors are mine.

1. Michael J. Gerhardt \& Michael Ashley Stein, The Politics of Early Justice: Federal Judicial Selection, 1789-1861, 100 Iowa L. REv. 551 (2015).
} 
Gerhardt and Stein. ${ }^{2}$ These commentators seemingly disagree about how to characterize the nomination and confirmation processes in the early Republic, but they apparently concur that it surpassed hyperpartisan modern appointments. ${ }^{3}$ The nomination and confirmation processes have spiraled downward, specifically throughout the administration of President Barack Obama. Senator Charles "Chuck" Grassley (R-Iowa) has figured prominently in selection, initially as Ranking Member of the Judiciary Committee and currently as Chair. The process has now devolved into rampant dysfunctionality, characterized by accusations, countercharges, paybacks, and obstruction whereby Republicans and Democrats ratchet down the stakes.

When the Republican Party ("GOP") captured an upper chamber majority in November 2014, some observers appeared cautiously optimistic about the potential for enhancement, mainly because Republican Senators have promised that they would directly bring regular order to the chamber again.4 Unfortunately, nominations and confirmations have yet to improve, and the GOP might actually have exacerbated the circumstances. This Essay undertakes an analysis of the 114th Congress's lack of improvement and offers solutions to this problem.

Ever since Republicans won the Senate, 5 the leadership has repeatedly pledged that it would restore the world's greatest deliberative body to "regular order."6 Members duly recited this short phrase to describe the reinstitution of the normal procedures which ostensibly governed the chamber before Democrats jettisoned those procedures when in the Senate majority from 2007 until 2014. On January 7, 2015, the 114th Senate's initial business day, Senator Mitch McConnell (R-Ky.), the newly-minted Majority Leader, admonished that "[w]e need to return to regular order," and he dutifully reiterated that de rigueur litany during the ensuing months. ${ }^{7}$ Senator

2. Jed Handelsman Shugerman, The Golden or Bronze Age of Judicial Selection?, 100 IowA L. Rev. BuLL. 69 (2015).

3. See Gerhardt \& Stein, supra note 1, at 615; Shugerman, supra note 2, at 76.

4. See, e.g., Sarah Binder, Can Mitch McConnell Repair the Senate?, WASH. PosT: MonKEy CAGE (Nov. 12, 2014), http://www.washingtonpost.com/blogs/monkey-cage/wp/2014/11/12/canmitch-mcconnell-repair-the-senate.

5. Jerry Markon et al., Republicans Win Senate Control as Polls Show Dissatisfaction with Obama, WASH. POST (Nov. 4, 2014), http://www.washingtonpost.com/politics/senate-control-atstake-in-todays-midterm-elections/2014/11/04/e882353e-642c-11e4-bb14-

4cfea1e742d5_story.html; Jonathan Weisman \& Ashley Parker, Riding Wave of Discontent, G.O.P. Takes Senate, N.Y. TIMES (Nov. 4, 2014), http://www.nytimes.com/2014/11/05/us/politics/midterm-elections.html.

6. See, e.g., Binder, supra note 4; Jennifer Steinhauer \& Jonathan Weisman, N.S.A. and Other Matters Leave McConnell's Senate in Disarray, N.Y. Times (May 23, 2015), http://www.nytimes.com/ 2015/05/24/us/politics/nsa-and-other-matters-vex-senate-leader-and-leave-disarray.html.

7. 161 Cong. Rec. S28 (daily ed. Jan. 7, 2015) (statement of Sen. McConnell); see also id. at S133 (daily ed. Jan. 12, 2015) (statement of Sen. McConnell) (commenting on Congress "getting back to work under a new Republican majority"); id. at S2767 (daily ed. May 12, 2015) (statement of Sen. McConnell) ("I know the opportunity to consider complex legislation via regular order 
Grassley, the Chair of the Senate Judiciary Committee, expressed analogous perspectives in multiple contexts. Symptomatic was his January 21 announcement that the panel would deploy regular order when considering judicial nominees, 8 and the declaration one week later that the committee would follow regular order when scrutinizing Eastern District of New York U.S. Attorney Loretta Lynch, the President's nominee for Attorney General. ${ }^{9}$ John Cornyn (R-Tex.), the Assistant Majority Leader, resoundingly echoed these sentiments in panel deliberations and exchanges on the floor. 10

Now that the 114th Congress has reached the first session's conclusion, the purported application of regular order to a major Senate constitutional duty-rendering advice and consent on presidential nominees-merits analysis. 11 This evaluation illuminates serious deficiencies, which plagued 2015 confirmations. Especially important was the GOP's failure to expeditiously suggest aspirants for White House consideration, and specifically failing to fill "judicial emergencies," provide hearings and ballots swiftly, conduct floor debates when required rapidly, and confirm more than 11 judges all year. This obstruction has numerous deleterious consequences; the most significant, however, is not fulfilling the constitutional responsibility to proffer advice and consent on many nominees. This subverts coordinate branch actions. The courts may now lack the judicial resources which they need to quickly, inexpensively, and equitably conclude litigation, while the delay may deprive the President of higher-level officers who insure the laws' faithful execution.

became too uncommon in recent years, but that is changing now."). But see id. at S2949 (daily ed. May 18, 2015) (statement of Sen. Reid) (commenting on '[t]he Republicans' refusal to consider the President's judicial nominations"); id. at S3223 (daily ed. May 21, 2015) (statement of Sen. Leahy) (blaming the Republicans for the limited number of Senate confirmations); Jim Manley, Has the Senate Really Turned a Corner?, WALl Street J.: WASh. Wire (June 24, 2015, 6:04 PM), http://blogs.wsj.com/washwire/2015/06/24/ has-the-senate-really-turned-a-corner.

8. News Release, Senator Charles Grassley, Chairman, Senate Comm. on the Judiciary, Judiciary Committee Holds First Nominations Hearing (Jan. 21, 2015), http://www.grassley.senate. gov/news/news-releases/judiciary-committee-holds-first-nominations-hearing ("[I]t is the first time [that these nominees] are appearing before the committee under regular order.").

9. Attorney General Nomination, U.S. SENATE COMmitTEe on the JudiCiaRY (Jan. 28, 2015), http://www.judiciary.senate.gov/meetings/attorney-general-nomination (click embedded video to listen to full hearing); see also David Catanese, Chuck Grassley's Gavel Year, U.S. NEWS \& WoRLD REP. (Jan. 28, 2015, 12:01 AM), http://www.usnews.com/news/articles/2015/01/28/chuck-grassleysgavel-year. For a recitation of Ms. Lynch's qualifications, see Press Release, White House, Office of the Press Sec'y, Remarks by the President at Nomination of Loretta Lynch for Attorney General (Nov. 9, 2014, 11:27 AM), https://www.whitehouse.gov/the-press-office/2014/11/09/remarks-presidentnomination-loretta-lynch-attorney-general.

10. Executive Business Meeting, U.S. SenAte CommitTeE on the Judiciary (Feb. 26, 2015), http://www.judiciary.senate.gov/meetings/executive-business-meeting-2015-02-26 [hereinafter Feb. 26 Executive Business Meeting] (click embedded video to listen to full meeting); see also 161 Cong. Rec. S703 (daily ed. Feb. 2, 2015) (statement of Sen. Cornyn) ("Mr. President, I ask for regular order."). Panel members discuss and vote on nominees at Executive Business Meetings.

11. U.S. ConST. art. II, § 2, cl. 2. 


\section{Non-Appeals Court And EXeCUTIVE Nomination AND CONFIRMATION PROCESSES}

\section{A. THE NON-APPEALS COURT PROCESSES}

\section{The Nomination Process}

The White House consults and seeks advice and recommendations from elected officials on well-qualified, consensus judicial prospects from their home states. The Obama Administration typically follows the officials' advice by nominating these candidates. 12 Those practices facilitate confirmations, as most Senators defer to their colleagues who represent the particular states in which vacancies arise because these Senators can effectively place vetoes on nominees by retaining blue slips-a custom which allows their choices to advance.13 Despite insistent White House cultivation of many legislators, a number have minimally cooperated by slowly creating procedures or tendering candidates. A few lawmakers have even neglected to suggest prospects. 14 Indeed, 36 of 43 (including 9 of 10 appellate court) judicial vacancies without nominees, 15 and 20 of 23 openings that the Administrative Office of the U.S. Courts ("AO") designates "judicial emergencies" that lack candidates, are in jurisdictions that at least one GOP Senator represents. 16

The clearest example is Texas. The most vacancies nationwide are in Texas, despite the confirmation of three able, uncontroversial jurists last year.17 It presently has two appellate court openings, both designated judicial emergencies, and eight district court vacancies, seven of which are judicial

12. Sheldon Goldman et al., Obama's First Term Judiciary: Picking Judges in the Minefield of Obstructionism, 97 Judicature 7, 15-17 (2013); Carl Tobias, Senate Gridlock and Federal Judicial Selection, 88 Notre Dame L. Rev. 2233, 2240 (2013).

13. See generally Ryan C. Black et al., Qualifications or Philosophy? The Use of Blue Slips in a Polarized Era, 44 PRESIDENTIAL STUD. Q. 290 (2014); Goldman et al., supra note 12, at 16-18.

14. See Goldman et al., supra note 12, at 17; see also Texas: State of Judicial Emergency, ALLIANCE FOR JUST., http://www.afj.org/our-work/issues/judicial-selection/texas-epicenter-of-thejudicial-vacancy-crisis (last visited Oct. 21, 2015). But see Burgess Everett \& Seung Min Kim, Judge Not: GOP Blocks Dozens of Obama Court Picks, Politico (July 6, 2015, 8:08 PM), http://www.politico.com/

story/2015/07/payback-gop-blocks-obama-judge-picks-judiciary-119743 ("Sen. Jeff Sessions (RAla.) charged that the president's legal team seems to have little interest in working with him and Sen. Richard Shelby on filling their state's three vacancies").

15. Current Judicial Vacancies, U.S. CouRTs, http://www.uscourts.gov/judges-judgeships/ judicial-vacancies/current-judicial-vacancies (last visited Oct. 30, 2015).

16. Judicial Emergencies, U.S. CouRTs, http://www.uscourts.gov/judges-judgeships/judicialvacancies/judicial-emergencies (last visited Oct. 21, 2015). The AO, which is the federal judiciary's administrative arm, premises emergencies on the large magnitude of dockets and protracted length of vacancies. Judicial Emergency Definition, U.S. CouRTS, http://www.uscourts. gov/judges-judgeships/judicial-vacancies/judicial-emergencies/judicial-emergency-definition (last visited Nov. 7, 2015).

17. The strong support that these nominees enjoy from home-state senators as well as the nominees' overwhelming committee and floor votes demonstrate that they are able and uncontroversial. See infra Part II.A.4. 
emergencies.18 For many, the candidate recommendation process has apparently not begun or could be moribund. In the April 13, 2015 debate on the first Texas re-nominee, Senator Patrick Leahy (D-Vt.), the committee Ranking Member, asserted that "[t]here is no good explanation why it has taken us nearly [seven] months to vote on his nomination, nor is there a good reason for why we are not voting on the other two pending nominees to district court vacancies in Texas." 19 He specifically elaborated that " $[t]$ here are still two Fifth Circuit vacancies and seven other Federal district court vacancies in Texas for which there are no nominees." 20 He also claimed that the state has more than twice the unfilled posts of any other jurisdiction in the United States.21 The Texas openings constituted a third of America's emergency vacancies, and Senator Leahy "urge[d] the Texas Senators to work with the President," so the chamber could promptly receive nominees for all the openings. 22

\section{Judiciary Committee Hearings}

Senator Grassley convened the first hearing on January 21, 2015, two weeks after Congress started and before Lynch's hearing, promising to "consider[] well qualified, consensus" nominees in "regular order." 23 The Chair asserted that the public should expect no "discernible difference" between how the panel functions under GOP-versus Democraticleadership. $24 \mathrm{He}$ also intimated that the committee would assemble hearings every few weeks Congress was in session, a policy which Senator Leahy-

18. Current Judicial Vacancies, supra note 15; Judicial Emergencies, supra note 16; see also Goldman et al., supra note 12, at 17; Texas: State of Judicial Emergency, supra note 14.

19. 161 Cong. REC. S2104 (daily ed. Apr. 13, 2015) (statement of Sen. Leahy).

20. Id.

21. Id.

22. Id.; accord 161 Cong. REC. S2030 (daily ed. Mar. 26, 2015) (statement of Sen. Leahy). This seems attributable to Texas Senators' slow responses to existing vacancies and failure to anticipate future ones, the slow pace of the expert Texas Judicial Evaluation Commissions' applicant reviews, differences on candidates within the Texas Democratic House delegation and between its members and the Senators, and delayed White House action. Even when lawmakers have concurred on picks, they may have not always secured agreement with Obama. See Editorial, No Judge, No Justice, DALl. Morning NEws, http://www.dallasnews.com/opinion/editorials/2014 0704-editorial-no-judge-no-justice.ece (July 4, 2014, 8:25 PM); Natalie Knight, Texas Judicial Vacancy Flood Means Cornyn, Cruz Must Act, StAR-Telegram (Aug. 26, 2015), http://www.startelegram.com/opinion/opn-columns-blogs/other-voices/ article32481486.html. But see Sylvan Lane, Senate Fills South Texas Judgeship; First Confirmation Since GOP Takeover, DALL. MoRNING NEWS: TRAIL Blazers BLOG (Apr. 13, 2015, 6:10 PM), http://trailblazersblog.dallasnews.com/2015/

04/senate-fills-south-texas-judgeship-first-confirmation-since-gop-takeover.html.

23. News Release, Senator Charles Grassley, supra note 8; see also Jennifer Jacobs, Grassley's Checklist of Priorities, DES MoINES REG. (Jan. 7, 2015, 5:59 PM), http://www.desmoinesregister.com/story/ news/politics/2015/01/07/grassley-checklist-priorities-judiciary-committee/21394233.

24. Catanese, supra note 9. 
Senator Grassley's predecessor- effectuated the last three Congresses and which Senator Grassley-the Ranking Member over the past two-helped to implement. 25

Substantial differences regarding panel operations quickly arose, however. For example, Senator Grassley conducted another hearing seven weeks following the initial one, the third hearing was eight weeks later, and the Chair did not arrange the fourth until June 10, 2015.26 He convened the March hearing for only two judicial nominees and the last for three, in contrast with the five Senator Leahy typically evaluated per hearing. 27 The January 21, 2015 panel hearing was the second for a pair of strong, consensus Executive Branch re-nominees, prompting Leahy's assertion that "[i]n my 40 years in the Senate, I cannot remember a single time that a second hearing was held ... on uncontroversial nominees." 28 The Chair directly acknowledged that each candidate had testified in earlier hearings but retorted this was "the first time they... appear[ed] before the committee under regular order" because "it was not appropriate to hold the hearing last year during the lame duck session of Congress [and] getting the Senate back to regular order and respecting process matters to our side." 29

During the April 20, 2015 debate on the second Texas re-nominee, Senator Grassley explained that the GOP majority was "at about the same pace that the Democratically led Senate was in 2007 during the Bush administration. This is further confirmed when you compare the committee's work this year to 2007." 30 He stated that "at this point in the [2007 Senate], the committee had held three nominee hearings for a total of 10 judges," while the panel "[had] already held [four] nomination hearings" for "six judges and four executive nominees, including both the Attorney General and Deputy Attorney General nominees." 31 The Chair explained that the "Committee is treating the President's nominees extremely fairly" because the Senate had approved 309 choices, compared with the 273 that it approved for President

25. One may compare the frequency of hearings held in the Senate Judiciary Committee in the 114th and 113th Congresses-when Senator Grassley and Senator Leahy were respectively the Chair of the Committee-on the Committee's website. See Hearings \& Meetings, U.S. SENATE COMMITTEE ON THE JUDICIARY, http://www.judiciary.senate.gov/hearings (last visited Dec. 4, 2015).

26. See id. The second hearing was on March 11, 2015 and the third on May 6, 2015. Id.

27. Compare Nominations, U.S. Senate CommitTEe on the JudiCiaRY (June 10, 2015), http:// www.judiciary.senate.gov/meetings/nominations-06-10-15 [hereinafter June 10 Nominations], and Nominations, U.S. SENATE CommitTEe on THE JudiCiaRY (Mar. 11, 2015), http://www.judiciary. senate.gov/meetings/nominations [hereinafter Mar. 11 Nominations], with Judicial Nominations, U.S. SENATE COMmitTEE ON THE Judiciary (Sept. 9, 2014), http://www.judiciary.senate.gov/meetings/ judicial-nominations-2014-09-09, and Judicial Nominations, U.S. SENATE COMMITTEE ON THE JUDICIARY (Jan. 28, 2014), http://www.judiciary.senate.gov/meetings/judicial-nominations-2014-01-28.

28. Senate Judiciary Comm., Hearing on Nominations 1 (2015), http://www.judiciary. senate.gov/imo/media/doc/01-21-15-leahy-statement.pdf.

29. News Release, Senator Charles Grassley, supra note 8.

30. 161 ConG. REC. S2264 (daily ed. Apr. 20, 2015) (statement of Sen. Grassley).

31. Id. 
George W. Bush during a similar period. 32 Senate Minority Leader Harry Reid (D-Nev.) countered that the panel was "not having any hearings to speak of" while, by June 8 of President Bush's seventh year in office, "Democrats confirmed 18 judges, including 3 circuit court judges." ${ }^{3}$ He suggested that this was a vivid contrast to the four trial level jurists whom Republicans helped appoint over 2015.34

\section{Judiciary Committee Discussions and Votes}

Despite Senator Grassley's late January pledges, which he repeated at the February 12, 2015 meeting, Republicans held over votes from that session until February 26, 2015.35 This inactivity continued a practice, which the GOP had employed during President Obama's first six years, of postponing discussions and ballots on uncontroversial nominees calendared for initial scrutiny until the next committee meeting. ${ }^{36}$ Those whom Republicans delayed were Lynch and five well-qualified, moderate U.S. Court of Federal Claims re-nominees, whom the panel duly reported in November 2014 on unopposed voice votes. 37 The Chair also suspended ballots on four consensus district re-nominees, including two for emergencies, who all had powerful support from their party's home-state Texas and Utah committee members. 38

32. Id. at S2263-64 (statement of Sen. Grassley).

33. Id. at S3850 (daily ed. June 8, 2015) (statement of Sen. Reid).

34. Id.

35. Feb. 26 Executive Business Meeting, supra note 10; Executive Business Meeting, U.S. SENATE COMMITTEE ON JUdiciarY (Feb. 12, 2015), http://www.judiciary.senate.gov/meetings/ executive-business-meeting-2015-02-12 [hereinafter Feb. 12 Executive Business Meeting] (click embedded video to listen to full hearing); see also Josh Voorhees, Procedural Purgatory: It's Time to Stop Asking When Loretta Lynch Will Be Confirmed and Start Wondering if She Ever Will Be, SLATE (Mar. 29, 2015), http://www.slate.com/articles/news_and_politics/politics/2015/03/loretta_lynch_ confirmation_mitch_mcconnell_and_the_gop_have_delayed_it_but.html.

36. See, e.g., Executive Business Meeting, U.S. Senate CommitteE ON THE JUdiciary (Sept. 11, 2014), http://www.judiciary.senate.gov/meetings/executive-business-meeting-2014-09-11; News Release, Senator Charles Grassley, Chairman, Grassley Statement at Executive Business Meeting (Feb. 12, 2015), http://www.grassley.senate.gov/news/news-releases/grassley-statement-executivebusiness-meeting ("There are a number of requests to hold over [Ms. Lynch's] nomination, which I will honor."); see also Tobias, supra note 12, at 2242-43. Indeed, the GOP has not held over 16 of 360 Obama nominees.

37. Executive Business Meeting, U.S. Senate Committee on the Judiciary (Nov. 20, 2014), http://www.judiciary.senate.gov/meetings/executive-business-meeting-2014-11-20.

38. Senators John Cornyn (R-Tex), Ted Cruz (R-Tex.), Orrin Hatch (R-Utah), and Mike Lee (R-Utah) are members of the Senate Judiciary Committee. Nominations, U.S. SENATE COMmitTEE oN THE JUDICIARY (Jan. 21, 2015), http://www.judiciary.senate.gov/meetings/nominations-2015-0121 (click embedded video to watch entire hearing and hear these Senators' supportive statements); Feb. 26 Executive Business Meeting, supra note 10 (Senators' votes); see also Current Judicial Vacancies, supra note 15. 
Lynch had to wait another four weeks on a vote after Senator Grassley first declared that he would canvass her in regular order. 39

There are additional examples of delayed processing. Roseann Ketchmark, a consensus district court nominee, testified in a March 11, 2015 hearing but was only reported April 23, 2015.40 Four capable, noncontroversial trial-level picks appeared for a May 6, 2015 hearing yet did not receive Committee approval until one month later, 41 while the pair of able, uncontroversial district selections who testified in a June 10, 2015 hearing were similarly reported to the floor four weeks thereafter. 42 The Chair also would not hold meetings every week that Congress was in session, a profoundly different system from Senator Leahy's persistent scheduling of them over the past six years. 43

\section{Floor Debates and Votes}

A major test for Republican bipartisan leadership arose with the February 26, 2015 committee approval of nominees and the Majority Leader's decision respecting when to stage their floor debates and positive or negative final ballots. Senator McConnell had resisted expeditious concords on nominee debates and votes while he served as the Minority Leader in President Obama's first term and a half,44 requiring Democrats to pursue

39. Feb. 26 Executive Business Meeting, supra note 10; see also supra note 9 and accompanying text.

40. Mar. 11 Nominations, supra note 27; see also Executive Business Meeting, U.S. SENATE COMMITTEE ON THE JUDiciaRY (Apr. 23, 2015), http://www.judiciary.senate.gov/meetings/ executive-business-meeting-2015-04-23 [hereinafter Apr. 23 Executive Business Meeting]. Ketchmark's committee and floor votes and Senators' remarks about her show that she was a consensus nominee. See 161 CoNG. REc. S6457 (daily ed. Sept. 8, 2015).

41. Nominations, U.S. Senate Committee ON the Judiciary (May 6, 2015), http://www.judiciary.senate.gov/meetings/nominations-2015-05-06 [hereinafter May 6 Nominations]; see also Executive Business Meeting of the S. Comm. on the Judiciary, 114th Cong. (June 4, 2015).

42. June 10 Nominations, supra note 27; see also Executive Business Meeting, U.S. SENATE COMMITTEE ON THE JUDICIARY (July 9, 2015), http://www.judiciary.senate.gov/meetings/executivebusiness-meeting-07-09-15 [hereinafter July 9 Executive Business Meeting].

43. In fairness, on some weeks the panel apparently had no nominees or legislation to consider. For Senator Leahy's time as Chair, see, e.g., Executive Business Meeting, U.S. SENATE COMMITTEE ON THE JUDICIARY (June 26, 2014), http://www.judiciary.senate.gov/meetings/ executive-business-meeting-2014-06-26; Executive Business Meeting, U.S. SENATE COMmitTEE ON THE JUDICIARY (June 19, 2014), http://www.judiciary.senate.gov/meetings/executive-businessmeeting-2014-06-19; Executive Business Meeting, U.S. SENATE COMMITTEE ON THE JUdicIary (June 18, 2014), http://www.judiciary.senate.gov/meetings/executive-business-meeting-2014-06-18; Executive Business Meeting, U.S. Senate CommitTeE on the JudiCiaRY (Apr. 3, 2014), http://www. judiciary.senate.gov/meetings/executive-business-meeting-2014-04-03; Executive Business Meeting, U.S. SENATE COMMitTEe ON THE JUdiciary (Mar. 27, 2014), http://www.judiciary.senate.gov/ meetings/executive-business-meeting-2014-03-27.

44. 158 Cong. Rec. S8375 (daily ed. Dec. 21, 2012) (statement of Sen. Leahy) ("[0]ver the last four years, Senate Republicans have chosen to depart dramatically from Senate traditions in their efforts to delay and obstruct President Obama's judicial nominations."); see also Tobias, 
cloture ballots on numerous suggestions and ultimately to alter filibusters by unleashing the "nuclear option." 45 However, Senator McConnell promised enhanced cooperation in his new role as Majority Leader.46 Scheduling court and executive nominee floor debates and votes provided a great opportunity for the Senator to fulfill this pledge. 47

Nevertheless, Senator McConnell assembled no swift chamber debates or ballots on the four district court and five Claims Court re-nominees whom the panel directly reported by voice vote on February 26, 2015. It was a month later, on March 26, when he finally set an April 13, 2015 debate and ballot for a lone district re-nominee, which apparently came in response to Senator Leahy's contention that the GOP refusal over the entire year "to schedule votes on any Federal judges is completely contrary to historical precedent" and "in stark contrast to the way Democrats treated President Bush's judicial nominees," especially in the administration's last two years when the majority "continued to hold regular hearings on judges and... confirmed 68 district and circuit court" nominees.48 The Ranking Member added: "[B]y the end of March 2007, the new Senate Democratic majority had confirmed 15 of President Bush's" trial and circuit aspirants, compared to none whom

supra note 12, at 2243; Juan Williams, Opinion, McConnell Misfires in Senate, THE HILL (June 22, 2015, 6:00 AM), http://thehill. com/opinion/juan-williams/245619-juan-williams-mcconnellmisfires-in-senate.

45. On a majority vote, Democrats changed the rules for cloture from 60 votes to a majority. 159 Cong. REc. S8418 (daily ed. Nov. 21, 2013); see also Carl Hulse, Harry Reid to Retire From Senate in 2016, N.Y. TIMES (Mar. 28, 2015), http://www.nytimes.com/2015/03/28/us/politics/ senator-harry-reid-retire.html ("Unhappy with the slow pace of judicial and executive branch confirmations, Mr. Reid engineered a change in Senate procedure in 2013 that allowed Democrats to overcome filibusters against nominees with a simple majority."); Jeffrey Toobin, How Harry Reid Changed The Federal Courts, NEW YORKER (Mar. 27, 2015), http://www.new yorker.com/news/news-desk/how-harry-reid-changed-the-federal-courts ("[I]n December, 2013, Reid invoked what became known as the nuclear option. With Reid's blessing, Senate Democrats changed the rules so that only a majority would be required to move lower-court judgeships to a vote.").

46. Binder, supra note 4; see also Sarah Binder, Why Can't Mitch McConnell Keep His Promises?, WASH. Post: Monkey CAGE (May 26, 2015), https://www.washingtonpost.com/blogs/monkey-cage/wp/2015/05/26/why-cant-mitchmcconnell-keep-his-promises; Steinhauser \& Weisman, supra note 4 (noting that as Senators departed for Memorial Day Recess, "they left behind a wreck of promises made by Mr. McConnell on how a renewed Senate would operate").

47. See Neil Eggleston, Judicial Nominations: Accomplishments and the Work That Lies Ahead, WhiteHousE.Gov: BLOG (Dec. 17, 2014, 3:39 PM), https://www.whitehouse.gov/blog/2014/12/ 17/judicial-nominations-accomplishments-and-work-lies-ahead; Colleen McCain Nelson \& Michael R. Crittenden, Obama Tries to Woo GOP on His Priorities, WALL STREET J. (Jan. 13, 2015, 7:29 PM), http:// www.wsj.com/articles/obama-congressional-leaders-discuss-how-to-spur-economic-progress-

14211690

18.

48. 161 Cong. Rec. S2029 (daily ed. Mar. 26, 2015) (statement of Sen. Leahy); see also id. at S2104 (daily ed. Apr. 13, 2015) (statement of Sen. Leahy). 
Republicans had approved to that point in 2015.49 Moreover, Leahy contended the "fact that we are in the last 2 years of this presidency does not mean our work is done" and that "[t]he Senate must continue to fulfill its constitutional obligation of advice and consent" while promptly authorizing 73 new judgeships proposed by the Judicial Conference that would afford courts resources for delivering justice.50 Senator Leahy responded to Senator Grassley's argument that 11 of the candidates appointed in the 2014 lame duck session must "count towards confirmations this year" by admonishing that earlier "Congresses have always confirmed consensus nominees prior to long recesses" and that "Democrats were only forced to do so because Republican obstruction had left judicial vacancies close to . . 90 through the first six years of [Obama's] tenure." 51

During the April 13, 2015 debate on the first Texas re-nominee, Senator Leahy charged that "baseless political obstructionism ... has also led to the Senate's failure to confirm a single Federal judge so far this year," and that "[d]espite promises to govern responsibly, the Republican majority has continued to obstruct" nominees." 52 He characterized the greater than three months consumed to "vote on a single nominee" as disconcerting, especially because "all four of the ... nominees who have been languishing on the Senate floor were recommended to President Obama by their two Republican home state [S]enators," and Senator Leahy collegially pleaded with the GOP to set ballots for ten other uncontroversial individuals awaiting votes on the Executive Calendar. 53

Senator McConnell did not publicly state when Republicans planned to schedule debates and ballots on the remaining three of four district court renominees or on any of the five Court of Federal Claims re-nominees, whom the panel approved with Ms. Lynch. Nonetheless, the Majority Leader considered one district re-nominee on April 20, 2015, provoking Leahy to exclaim that nominee Judge George Hanks "is just the second judicial nominee that we

49. Id. at S2030 (daily ed. Mar. 26, 2015) (statement of Sen. Leahy); accord supra note 33 and accompanying text.

50. 161 Cong. Rec. S2029 (daily ed. Mar. 26, 2015) (statement of Sen. Leahy). The Judicial Conference is the federal courts' policymaking arm, which premises suggestions for Congress on conservative estimates of work and caseloads. See JUDICIAL CONFERENCE OF THE U.S., REPORT OF THE Proceedings of the Judicial Conference of the United States 18-19 (Mar. 10, 2015), http://www.uscourts.gov/file/18176/download.

51. 161 CONG. REC. S2029-30. For consensus nominees' approval, see Goldman et al., supra note 12, at 13-14; Michael L. Shenkman, Decoupling District from Circuit Judge Nominations: A Proposal to Put Trial Bench Confirmations on Track, 65 ARK. L. Rev. 217, 292 (2012). For the 90 vacancies idea, see Current Judicial Vacancies, supra note 15. See also Goldman et al., supra note 12 , at 14 (discussing how the courts "already have about 80 vacancies" (quoting an unnamed senior aide)).

52. 161 Cong. REC. S2104 (daily ed. Apr. 13, 2015) (statement of Sen. Leahy).

53. Id. at $\mathrm{S} 2104-05$. 
have voted to confirm more than [three] months into the 114th Congress." 54 That proved to him that the GOP "delay and obstruction" witnessed in the earlier Obama years was recurring. $55 \mathrm{He}$ decried the "slow trickle of confirmations ... [which] is undermining" federal courts' efficacious operation and "hurting the American people," and repeated his call for speedy appointment of the judicial designees "pending on the Executive Calendar." 56 Senator Grassley responded to Senator Leahy by asserting that the chamber was "moving judicial nominees at about the same pace as we did at this point in President Bush's" seventh year. 57 However, the Chair's declaration was premised on the charge that Democrats violated "standard practice" by approving 11 judicial nominees whom the committee reported in the lame duck session and, thus, when those 11 confirmees are included, the year's pace resembled the Democrats' pace in 2007.58

When Senator McConnell persistently refused to set ballots for the last pair of district re-nominees, Senator Reid declared on May 6, 2015, that the GOP had confirmed only two persons the whole year, as contrasted with 16 appointments in 2007, and that emergencies had doubled over 2015.59 The Minority Leader also stated that 20 recommendations were pending before the committee.60 He described Republicans' failure to discharge their constitutional responsibility as "an injustice to the American people" and urged the GOP to heed this solemn duty.61 When Senator McConnell was apparently unresponsive to these pleas, Senator Reid reiterated the concerns articulated two weeks before, while concentrating on Texas's "seven judicial emergencies, the most of any" jurisdiction, and Senator Cornyn's inability to deliver final votes, notwithstanding promises of rapid confirmation.62 Those actions seemingly prompted Senator McConnell to schedule eleventh-hour nominee floor consideration immediately ahead of the Memorial Day recess for a pair of trial court re-nominees to emergency vacancies who had been waiting almost 90 days since the panel report.63

54. Id. at S2264 (daily ed. Apr. 20, 2015) (statement of Sen. Leahy); see also Jennifer Steinhauer, McConnell Makes Changes, but Senate Gridlock Remains, N.Y. TimES (Mar. 20, 2015), http://www.nytimes.com/2015/03/21/us/politics/mitch-mcconnell-makes-changes-but-senategridlock-remains.html?_r=1; supra notes 20-22 and accompanying text.

55. 161 ConG. REC. S2264 (daily ed. Apr. 20, 2015) (statement of Sen. Leahy).

56. Id.

57. Id. at $\mathrm{S} 2263$ (statement of Sen. Grassley).

58. Id. at S2264. But see supra notes 30-31 and accompanying text.

59. 161 ConG. Rec. S2659 (daily ed. May 6, 2015) (statement of Sen. Reid).

60. Id. at $\mathrm{S} 2949$ (daily ed. May 18, 2015) (statement of Sen. Reid).

61. Id. at S2659 (daily ed. May 6, 2015) (statement of Sen. Reid).

62. Id. at S2949 (daily ed. May 18, 2015) (statement of Sen. Reid).

63. See id. at S3224 (daily ed. May 21, 2015) (confirming Jill N. Parrish to be United States District Judge for the District of Utah and Jose Rolando Olvera, Jr. to be United States District Judge for the Southern District of Texas). 
Senator Leahy capitalized on the May 21, 2015 debate, which involved those aspirants to critically evaluate and summarize the 2015 judicial confirmation process. He observed that in September 2014 Obama tapped both individuals, who consequently enjoyed January hearings and unanimous February committee approvals but had languished on the floor nearly three months. 64 Senator Leahy proclaimed that Jose Olvera, the Texas re-nominee, would fill "one of six district court emergency vacancies in" Texas, which had eight trial level openings at that date. 65 He repeated that the Senate has a "duty to fill vacancies no matter which party holds the majority" and reminded colleagues that Democrats helped appoint 68 lower court nominees in President Bush's last two years and 18 in the comparable time when Republicans approved merely four.66 Senator Leahy concomitantly asserted that GOP leaders keep affording "excuses for their continued obstruction and delay on confirming judicial nominees." 67 For instance, he responded to Senator Grassley's proclamation that Democrats were only able to confirm 18 judges in 2007 because those selections were held over from 2006 by asserting that Republicans failed to observe that "nine of the judges confirmed... were not [actually] among those left pending on the Senate Executive Calendar at the end of 2006." 68 Leahy also directly criticized the GOP justifications, as they "miss the bigger picture" of the responsibility to swiftly fill court vacancies by practicing "delay for delay's sake" and reiterated that emergencies had doubled this year.69 He finished by canvassing all ten nominees waiting for chamber votes and championing their prompt appointment.70 Following multiple laudatory remarks by home-state politicians, the Senate confirmed both nominees 100-0.71

The Majority Leader as well did not publicly reveal when the seven other district nominees who captured hearings and votes by July would receive final consideration until immediately before he scheduled the floor ballots. The designee with a March committee hearing and April panel vote finally received a September 8, 2015 floor ballot.72 The four nominees who testified

64. Id. at S3223 (daily ed. May 21, 2015) (daily ed. May 21, 2015) (statement of Sen. Leahy); see also supra notes 23,35 and accompanying text.

65. 161 Cong. REC. S3223 (daily ed. May 21, 2015) (statement of Sen. Leahy); see also supra notes 20, 56 and accompanying text.

66. 161 CoNG. REC. S3223 (daily ed. May 21, 2015) (statement of Sen. Leahy).

67. Id.

68. Id.

69. Id.; see also supra note 55 and accompanying text.

70. 161 ConG. REC. S3223 (daily ed. May 21, 2015) (statement of Sen. Leahy). He stressed the Court of Federal Claims nominees whom Obama first named a year earlier. Id. All of his ideas deflate the regular order mantra.

71. Id. at $\mathrm{S} 3224$.

72. See Apr. 23 Executive Business Meeting, supra note 40; Mar. 11 Nominations, supra note 27; see also 161 Cong. REC. S6457 (daily ed. Sept. 8, 2015) (Roseann Ketchmark's confirmation vote). 
in the May committee session and captured June panel approval concomitantly attained final votes only in October and November, because Senator Grassley objected to the July 30, 2015 unanimous consent request seeking floor ballots on three of those nominees from Senator Charles Schumer (D-N.Y.) by repeating the Chair's ideas regarding the 2014 lame duck session approvals (which contravened regular order) and how 2015 was analogous to 2007, asking Schumer to "put that in [his] pipe and smoke it." 73 One of the two of Tennessee district nominees, who testified in the June 10, 2015 hearing and received July panel approval, and the five Court of Federal Claims re-nominees, who first earned committee approval in November 2014, were still awaiting final votes in January 2016.74

\section{B. EXECUTIVE BRANCH CONFIRMATION PROCESS}

On November 8, 2014, President Obama tapped Loretta Lynch for Attorney General. He characterized her as a superbly qualified, dedicated public servant to replace Eric Holder, the Attorney General during the Chief Executive's tenure to that point.75 Senator Leahy had planned to arrange a hearing during 2014, but he acceded to the minority's request that it be suspended until the 114th Congress assembled because the new Majority Leader pledged that "she would be treated fairly." 76 At the commencement of Lynch's hearing, Senator Grassley vowed to employ regular order in processing her.77 She answered eight hours of complex, difficult queries and even certain requests that could be deemed questionable because they related to President Obama's immigration policies.78 "Not a single witness" for the majority party opposed her.79 The Chair declared that the record would be

73. 161 Cong. REC. S6151-52 (daily ed. July 30, 2015); July 9 Executive Business Meeting, supra note 42; June 10 Nominations, supra note 27; see also 161 Cong. Rec. S7961 (daily ed. Nov. 16, 2015) (LaShann Montique DeArcy Hall's confirmation vote); id. at S7488 (daily ed. Oct. 26, 2015) (Lawrence Vilardo's confirmation vote); id. at S7314 (daily ed. Oct. 20, 2015) (Ann Donnelly's confirmation vote); id. at S7117 (daily ed. Oct. 5, 2015) (Dale Drozd's confirmation vote).

74. See June 10 Nominations, supra note 27; see also July 9 Executive Business Meeting, supra note 42. On December 7, the Senate confirmed Travis McDonough, one Tennessee nominee. 161 CoNG. REC. S8443 (daily ed. Dec. 7, 2015).

75. Press Release, White House, Office of the Press Sec'y, supra note 9; see also Michael D. Shear, Eric Holder Resigns, Setting up Fight over Successor, N.Y. Times (Sept. 25, 2014), http://www.nytimes. com/2014/09/26/us/politics/eric-holder-resigning-as-attorneygeneral.html?_r=2.

76. 161 ConG. Rec. S2028-29 (daily ed. Mar. 26, 2015) (statement of Sen. Leahy).

77. See Attorney General Nomination, supra note 9 (click embedded video to listen to full hearing).

78. See id. (showing the hearing's length and providing examples of requests for Lynch's opinion regarding the legality of certain aspects of the Obama Administration's immigration policy).

79. 161 Cong. Rec. S2104 (daily ed. Apr. 13, 2015) (statement of Sen. Leahy); see also id. at S2029 (daily ed. Mar. 26, 2015) (statement of Sen. Leahy) (claiming Rudy Giuliani, ex-GOP New 
open for the delivery of written queries, and Lynch swiftly provided answers to some 900.80

During the February 12, 2015 Executive Business Meeting, the GOP exercised its prerogative to routinely suspend a discussion and ballot until the next meeting. 81 Following rigorous debate at the February 26 session, virtually none of which covered Lynch's qualifications, the committee approved her on a $12-8$ bipartisan vote. 82

Senator McConnell issued a March 10, 2015 promise that Republicans would stage Lynch's ballot the next week, 83 yet a controversy erupted when Democrats found that Republicans had placed "Hyde amendment" wording in the Justice for Victims of Trafficking Act of 2015,84 which caused Democrats to filibuster this bill.85 On March 15, 2015, the Majority Leader swiftly revoked the pledge to schedule Lynch's debate and vote the ensuing week, threatening that he would arrange neither until the opposition party relented on the human trafficking conundrum. ${ }^{86}$ These machinations drove the Ranking Member to lambast the GOP for abandoning the "solemn duty to consider nominees" for integral executive positions, specifically a post so important

York City Mayor "and a proud law-and-order conservative," and Louis Freeh, former FBI Director and federal judge, strongly praised Lynch).

80. Attorney General Nomination, supra note 9; see also 161 ConG. REC. S2104 (daily ed. Apr. $13,2015)$ (statement of Sen. Leahy) ("Ms. Lynch ... responded to nearly 900 written questions.").

81. See Feb. 12 Executive Business Meeting, supra note 35 (click embedded video to watch the full meeting).

82. See Feb. 26 Executive Business Meeting, supra note 10 (click embedded video to watch the full meeting).

83. Mike DeBonis, Loretta Lynch Confirmation Vote Will Come Next Week, McConnell Says, WASH. POST (Mar. 10, 2015), http://www.washingtonpost.com/news/postpolitics/wp/2015/03/10/

loretta-lynch-confirmation-vote-will-come-next-week-mcconnell-says; see also Seung Min Kim \& Burgess Everett, Lynch Still Stalled by Abortion Fight, Politico (Apr. 13, 2015, 5:50 AM), http:// www.politico.com/story/2015/04/lynch-still-stalled-by-abortion-fight-116908.

84. The legislation at issue was S. 178, 114th Cong. (2015). The bill has since been amended and enacted. Justice for Victims of Trafficking Act of 2015, Pub. L. No. 114-22, 129 Stat. 227 (to be codified in scattered sections of $6,18,31,42$ U.S.C.).

85. 161 Cong. Rec. S2161 (daily ed. April 14, 2015); see also Jennifer Steinhauer, SexTrafficking Bill Ensnared by Politics, Is Left in Limbo by a Senate Vote, N.Y. TimEs (Mar. 17, 2015), http://www.nytimes.com/2015/03/18/us/politics/impasse-over-sex-trafficking-bill-showsdepth-of-rancor-in-congress.html. The Hyde Amendment prohibits the expenditure of federal funds on abortions. Pub. L. No. 94-439, § 209, 90 Stat. 1434 (1976); see also S. 219, 114th Cong. (2015) (introducing the "Hyde Amendment Codification Act").

86. See Michael R. Crittenden, Fight Over Abortion Grinds Senate to Halt, WALl StREET J. (Mar. 19, 2015, 7:43 PM), http://www.wsj.com/articles/fight-over-abortion-grinds-senate-to-halt1426

808606; Jonathan Weisman \& Jennifer Steinhauer, In Delaying Vote on Loretta Lynch as Attorney General, G.O.P. Is in a Quandary, N.Y. TimEs (Mar. 29, 2015), http://www.nytimes.com/2015/03/ 30/us/politics/in-holding-up-loretta-lynch-attorney-general-nominee-gop-is-in-a-

quandary.html; Interview with Mitch McConnell, Senate Majority Leader, on CNN State of the Union (Mar. 15, 2015) (transcript available at http://www.cnn.com/TRANSCRIPTS/1503/15/sotu.01.html). 
"to ... national security and our most cherished civil rights," turning "this vital position - and the highly respected nominee-into a bargaining chip to be leveraged for political gain" and openly connecting the selection's approval "to partisan politics by linking her vote to demands on legislation." 87 Senator Leahy admonished that failure to consider Lynch ahead of the coming April recess (which did not occur) meant that, when the chamber reconvened, she would have been pending before the full Senate "nearly twice as long as all of the past seven Attorneys General combined." 88 Senator Leahy found the delay an "embarrassment for the... Senate" and warned that "hav[ing] to file a cloture motion and vote to overcome a filibuster.... [w]ould be unprecedented." 89

With the chamber's April 13, 2015 return, Senator Leahy directly reiterated his criticism of the GOP for "baseless political obstructionism that has stalled Ms. Lynch's nomination" and the extensive time the prospect had waited in contrast to the last seven nominees for the post and demanded that she receive a quick ballot.90 One week later, he contended that Lynch's treatment exemplified "how Republicans approach our constitutional role of advice and consent." 91 Senator Leahy agreed with President Obama that Senate dysfunction went "too far" and repeated how long Lynch had waited. 92 Making a distinguished executive nominee's final vote contingent on resolving a dispute about legislation that was completely unrelated to her candidacy's merits violated regular order. Accordingly, Lynch had no debate and ballotwhich required a cloture vote due to an unprecedented filibuster-before April's conclusion, over six months after President Obama tendered her.93 Nonetheless, the Minority Leader reminded his colleagues that Lynch was among numerous, important executive choices, including diplomats and agency heads, whom Republicans failed to expeditiously process, claiming

87. 161 ConG. REC. S2028-29 (daily ed. Mar. 26, 2015) (statement of Sen. Leahy). Leahy criticized Cornyn for describing Democrats' concern about delay as "faux outrage" and applying double standards, as he castigated Democrats for delaying much faster review of Michael Mukasey, Bush's 2007 nominee. Id. at S2029; accord id. at S2104 (daily ed. Apr. 13, 2015).

88. Id. at S2029 (daily ed. Mar. 26, 2015) (statement of Sen. Leahy); accord id. at S2104 (daily ed. Apr. 13, 2015); id. at S2264 (daily ed. Apr. 20, 2015).

89. Id. at S2029 (daily ed. Mar. 26, 2015) (statement of Sen. Leahy).

90. Id. at S2104 (daily ed. Apr. 13, 2015) (statement of Sen. Leahy).

91. Id. at S2264 (daily ed. Apr. 20, 2015) (statement of Sen. Leahy); see also Juliet Eilperin \& Steven Mufson, Obama Blasts Senate over Stalled Lynch Confirmation, Calling It an "Embarrassing" Example of "Dysfunction," WASH. PoST (April 17, 2015, 2:10 PM), http://www.washingtonpost.com/ news/post-politics/wp/2015/04/17/trying-his-hand-at-italian-obama-meets-with-primeminister-renzi-on-friday; Christi Parsons \& Timothy M. Phelps, Obama to Senate: Delay on Attorney General Vote is "Embarrassing," L.A. Times (Apr. 17, 2015, 11:44 AM), http://www.latimes.com/nation/ politics/politicsnow/la-pn-obama-lynch-nomination-20150417-story.html.

92. 161 ConG. ReC. S2264 (daily ed. Apr. 20, 2015) (statement of Sen. Leahy).

93. Id. at S2378 (daily ed. Apr. 23, 2015); see also supra notes 9, 85 and accompanying text. 
they "[we]re holding up basically all" Obama candidates, and using Lynch as the quintessential example. 94

\section{SUMMARY}

In short, despite constant invocation of the "regular order" trope by prominent GOP leaders since the party won the chamber, from January 6, 2015 until April 12, 2015 they could not manage to approve a sole district judge, while confirming only ten district judges and one circuit jurist all year. Prior to June 2015, the committee also granted merely three hearings for judicial nominees and one encompassed only two selections. The panel allowed merely four district and five Court of Federal Claims re-nominees ballots on February 26, 2015 and two more judicial nominee votes in late April of that year.95 Loretta Lynch, the chief executive's highly qualified Attorney General nominee, correspondingly waited longer for appointment than her seven predecessors combined and was the sole nominee for that position in U.S. history to confront a filibuster. 96 This dismal record acutely contrasts with that of the Democrats in President Obama's first six years and their record in the Bush Administration. 97

\section{ApPellate Court Nomination And Confirmation Processes}

\section{A. KARA FARNANDEZ STOLL}

On November 12, 2014 President Obama nominated Kara Farnandez Stoll to the U.S. Court of Appeals for the Federal Circuit and District Judge Luis Felipe Restrepo to the U.S. Court of Appeals for the Third Circuit.98 The President has made no appellate nomination since, partly because GOP Senators represent the jurisdictions with vacancies that lack nominees and

94. 161 Cong. REC. S2660 (daily ed. May 6, 2015); see also Steve Benen, Senate GOP Delaying Lynch Nomination (Again), MSNBC (Mar. 24, 2015, 8:00 AM), http://www.msnbc.com/rachelmaddow-show/senate-gop-delaying-lynch-nomination-again; Jonathan Bernstein, Congress Earned Voters' Disrespect, BloombergView (Nov. 23, 2015, 9:30 AM), http://www.bloombergview.com/

articles/2015-11-23/senate-skips-town-earns-low-poll-ratings [hereinafter Bernstein, Congress] (asserting that "McConnell's partial government shutdown continues"); Jonathan Bernstein, Mitch McConnell's One-Man Shutdown, BLoombergView (May 22, 2015, 4:33 PM), http://www. bloombergview.com/articles/2015-05-22/mitch-mcconnell-s-one-man-shutdown.

95. See supra notes 27, 36-38, 40 and accompanying text.

96. See supra notes 85,88 and accompanying text.

97. 161 CONG. REC. S2029-30. Democrats' conduct, such as igniting the "nuclear option," apparently extended the "confirmation wars." See Tobias, supra note 12, at 2261.

98. Press Release, White House, Office of the Press Sec'y, President Obama Nominates Two to Serve on the United States Courts of Appeals (Nov. 12, 2014), https://www.whitehouse.gov/ the-press-office/2014/11/12/president-obama-nominates-two-serve-united-states-courts-appeals; Press Release, White House, Office of the Press Sec'y, Presidential Nominations Sent to the Senate (Jan. 7, 2015), https://www.whitehouse.gov/the-press-office/2015/01/07/presidentialnominations-sent-senate. 
those politicians have not coordinated well.99 Stoll was an experienced, mainstream Federal Circuit practitioner, and Restrepo is an exceptional, consensus jurist. 100 Both candidates are diverse in terms of ethnicity.101 The Committee granted neither nominee a 2014 hearing, mainly because Obama nominated them late in the year after Republicans had won the chamber.

Stoll earned a March 11, 2015 hearing, which proceeded smoothly.102 Nonetheless, the panel only conducted a vote on April 23, 2015, while it placed her on the Executive Calendar where the aspirant languished for weeks. 103 Senator McConnell did not publicly say when he might provide her a final ballot. Nevertheless, in early June, the Majority Leader suggested that the GOP could prevent floor votes on additional Obama circuit nominees. 104 After several press outlets reported this concept, a McConnell staffer admonished: "[W]e're going to continue to do judges. There's not a shutdown....We probably will have a circuit court nominee." 105

On June 8, 2015, Senator Reid accused the Majority Leader of drastic obstruction-namely refusing chamber floor ballots for all court of appeals picks-in violation of his constitutional duty.106 The Minority Leader referenced Senator McConnell's 2008 floor statements that demanded

99. Russell Wheeler, With Senate Control, Will the GOP Stop Confirming Circuit Court Judges?, BRooKINGS (June 10, 2015, 3:00 PM), http://www.brookings.edu/blogs/fixgov/posts/2015/ 06/10-circuit-court-confirmations-wheeler; see also supra notes 14-22 and accompanying text.

100. See Press Release, White House, supra note 98 (describing the qualifications of Stoll and Restrepo); see also 161 Cong. REC. S6456 (daily ed. Sept. 8, 2015) (statement of Sen. Leahy) (noting the qualifications of Restrepo); Scott Graham, Federal Circuit Nominee Sails Through Senate Confirmation, RECORDER (July http://www.therecorder.com/id=1202731562482/

Federal-Circuit-Nominee-Sails-Through-Senate-Confirmation?slreturn=20151104163703 (noting the qualifications of Stoll).

101. 161 CONG. REC. S6456 (daily ed. Sept. 8, 2015 (statement of Sen Leahy) ("Judge Restrepo w[ould] be[ the first Hispanic judge from Pennsylvania to serve on [the Third Circuit] ...."); Editorial, Confirm President Obama's Judges, N.Y. Times (Nov. 13, 2015), http://www.nytimes.com/2015/11/13/ opinion/confirm-president-obamas-judges.html?_r=0 ("As a Hispanic... Judge Restrepo would bring a needed measure of ethnic ... diversity to the court."); Everett \& Kim, supra note 14 ("[Stoll] would be the first minority woman to serve on the Federal Circuit...."); Gene Quinn, Kara Stoll Confirmed by Senate as Newest Judge on the Federal Circuit, IPWATCHDoG.Com (July 8, 2015), http://www.ipwatchdog.com/2015/07/08/kara-stollconfirmed-by-senate-as-newest-judge-on-the-federal-circuit/id=59635.

102. Mar. 11 Nominations, supra note 27.

103. Apr. 23 Executive Business Meeting, supra note 40. The panel did conduct more hearings on July 22, September 30, October 21, and December 9, 2015.

104. Steve Benen, McConnell's Silent Governing Failure, MSNBC (June 5, 2015, 3:08 PM), http://www.msnbc.com/rachel-maddow-show/mcconnells-silent-governing-failure; Burgess Everett \& Nick Gass, McConnell Vows to Slow Judicial Nominees, Politico (June 5, 2015, 1:06 PM), http://www.politico.com/story/2015/06/mitch-mcconnell-judicial-nominations-118674.

105. Alexander Bolton, McConnell Backs Away from Judicial Shutdown Talk, THE HiLl (June 6, 2015, 1:05 PM), http://thehill.com/homenews/senate/244196-mcconnell-backs-away-fromjudicial-shutdown-talk (quoting Mitch McConnell spokesman Don Stewart).

106. 161 CONG. REC. S3849-50 (daily ed. June 8, 2015) (statement of Sen. Reid). 
immediate votes on Bush appeals court nominees and observed that "[t]he Republican Senate hasn't confirmed even a single circuit court judge-not even a consensus nominee such as Kara Stoll."107 He urged her prompt approval.108 The Majority Leader has yet to clarify his allusions. When it became clear that the Senate was preparing to depart for the July 4, 2015 recess without having extended any nominee final consideration since late May, Senator Leahy protested the inertia, surveyed the lack of progress during 2015, and called for quick appointment of nominees on the Executive Calendar, most prominently Stoll, which putatively triggered her July 95-0 ballot.109 Of course, were the Senate to confirm a tiny number of appellate choices, this would violate "regular order," as it would certainly be unprecedented and the Democratic majority effectively helped approve numerous circuit jurists during Bush's last two years in office.110

\section{B. LUIS FELIPE RESTREPO}

The appointments process for the only remaining candidate submitted to fill the appeals court vacancies affords a compelling illustration of delay. Judge Restrepo, an experienced, uncontroversial Third Circuit nominee, waited seven months for a hearing. ${ }^{111}$ In November, Obama nominated the designee mostly on the strong bipartisan endorsement of Senators Bob Casey (D-Pa.) and Pat Toomey (R-Pa.) and re-nominated him in January for consideration by the 114th Senate.112 However, the panel did not set a hearing until June 10, 2015, primarily because Toomey only returned his blue slip on May 14, although Casey directly produced his in November 2014.113 Both Senators had earlier proffered Restrepo for the district bench, and the Senate confirmed him on a June 2013 voice vote.114 The legislators suggested Restrepo's elevation with a press release in which Senator Toomey claimed that he

107. Id. at $\mathrm{S} 3850$ (statement of Sen. Reid).

108. Id.

109. Leahy reiterated much data and the GOP duty. Id. at S4591-92 (daily ed. June 24, 2015) (statement of Sen. Leahy); see also id. at S4678 (daily ed. July 7, 2015) (statement of Sen. Leahy).

110. See supra notes 47-48, 50 and accompanying text.

111. 161 Cong. Rec. S2949 (daily ed. May 18, 2015) (statement of Sen. Reid) (reiterating criticism of GOP for delaying Restrepo and other nominees in committee and on floor).

112. See supra note 98 and accompanying text.

113. See Laura Olson, What's Holding Up a Pa. Appeals Court Nominee?, Morning Call (May 6, 2015, 3:32 PM), http://www.mcall.com/news/nationworld/pennsylvania/capitol-ideas/mc-whats-holdingup-a-pa-appeals-court-nominee-20150506-story.html; Saranec Hale Spencer, Toomey Submits Blue Slip, but Will Restrepo Get a Hearing?, LEGAL InTELLIGENCER (May 19, 2015), http://www.thelegal intelligencer.com/id=1202726785818/Toomey-Submits-Blue-Slip-but-Will-Restrepo-Get-a-Hearing?sl return=20151007134421; Jonathan Tamari, A Judicial Nominee Waits; Toomey Gets Blamed, PHILADELPHIA INQUIRER (May 8, 2015), http://articles.philly.com/2015-05-09/news/619523 88_1_toomey-luis-felipe-restrepo-president-obama.

114. 159 ConG. Rec. S4515-16 (daily ed. June 17, 2013); Spencer, supra note 113. Restrepo was then a Magistrate Judge on the U.S. District Court for the Eastern District of Pennsylvania. Id. 
would "make a superb addition to the Third Circuit." 115 Nonetheless, the aspirant was excluded from a May 6, 2015 hearing on four district nominees-merely the third conducted over 2015-although the chamber had been working for 13 weeks and Obama had picked no choice ahead of him. 116

The day before the hearing, reporters questioned Senator Toomey, who declared that he remained supportive of the nominee and confident about confirmation this year.117 Senator Grassley stated that the panel would schedule a hearing after Senator Toomey provided the blue slip, which the press reported he was retaining. ${ }^{118}$ A Grassley committee staffer alleged that the panel was canvassing the possibility's background under "regular process," 119 and lawmakers might "hold on to blue slips until the committee has finished vetting a nominee" because questions do arise in that evaluation. 120

115. Press Release, Senator Robert P. Casey, Jr., Casey, Toomey Applaud Nomination of Judge Luis Felipe Restrepo to U.S. Court of Appeals for the Third Circuit (Nov. 12, 2014), http://www.casey.senate.

gov/newsroom/releases/casey-toomey-applaud-nomination-of-judge-luis-felipe-restrepo-to-uscourt-of-appeals-for-the-third-circuit; see also Olson, supra note 113.

116. Mar. 11 Nominations, supra note 27; May 6 Nominations, supra note 41.

117. Jennifer Bendery, Pat Toomey Is Blocking His Own Judicial Nominee, for Some Reason, HuFFington Post (May 6, 2015, 2:59 PM), http://www.huffingtonpost.com/2015/05/05/pattoomey-luis-restrepo_n_7214790.html; see also Tracie Mauriello, Confirmation Vote on Pennsylvania Jurist Awaits "Blue Slip" from Toomey, PitT. Post-GAzETTE (May 7, 2015, 12:19 AM), http://www.

post-gazette.com/local/2015/05/06/Toomey-holding-up-confirmation-of-Pennsylvania-jurist-hesupports/stories/201505060171; Saranac Hale Spencer, Political Maneuvers Hold up Nominee for Third Circuit, LEGAL INTELLIGENCER (May 6, 2015), http://www.thelegalintelligencer.com/ id $=1202725590790 /$ Political-Maneuvers-Holding-Up-Nominee-for-Third-Circuit.

118. Bendery, supra note 117; Mauriello, supra note 117.

119. Spencer, supra note 117 (emphasis added) (quoting Beth Levine, spokeswoman for Senator Grassley). Ms. Levine claimed nominations are processed in the order received. Olson, supra note 113. However, the Senate has not always processed nominees in the order received. For instance, Obama nominated the three Texas re-nominees whom the Senate confirmed in 2015 the same day as other nominees whom the Senate confirmed in 2014. Press Release, White House, Office of the Press Sec'y, President Obama Nominates Seven to Serve on the United States District Courts (Sept. 18, 2015), https://www.whitehouse.gov/the-press-office/2014/09/18/ president-obama-nominates-seven-serve-united-states-district-courts. For confirmation of the first two Texas re-nominees, see 161 ConG. Rec. S2105 (daily ed. Apr. 13, 2015) (regarding Bennett); id. at S2264-65 (daily ed. Apr. 20, 2015) (regarding Hanks); see also supra note 71 and accompanying text (regarding Olvera, the third nominee). For the 2014 confirmation of three nominees nominated the same day, see 160 ConG. REc. S6908 (daily ed. Dec. 16, 2014). A telling recent example was Southern District of Iowa nominee Rebecca Ebinger, who received a hearing earlier than ten nominees who received nomination before her. Nominations, U.S. SENATE COMMITTEE ON THE JUdiCIARY (Oct. 21, 2015), http://www.judiciary.senate.gov/meetings/ nominations-10-21-15.

120. Mauriello, supra note 117 (quoting Beth Levine, spokeswoman for Senator Grassley); Olson, supra note 113; accord Jennifer Bendery, Toomey Insists He's Not Holding up a Nominee He's Holding Up, HufFINGTON POST (May 14, 2015, 7:59 PM), http://www.huffingtonpost.com/ 
At the opening of the May 6, 2015 chamber session, Senator Reid directly recited Senator Toomey's dramatic laudatory November comments on Restrepo while asking whether Pennsylvania citizens "[a]re ... left wondering why this qualified judicial candidate is not moving forward" and why Toomey neglected to speak on the floor "about [Restrepo] being held up by his own party." 121 Senator Grassley correspondingly submitted a prepared statement which demonstrated that the 2015 GOP record for assessing nominees was similar to that which Democrats had compiled when reviewing Bush prospects over the analogous 2007 year. 122

In subsequent days, the Pennsylvania Republican vehemently denied that he was stalling Restrepo, declared the committee was analyzing him but would only conduct a hearing after its conclusion, and vowed to produce the blue slip then, unless pertinent concerns surfaced.123 On May 14, 2015, Senator Toomey finally acquiesced, proffering his blue slip, purportedly because of the inquiry's end; yet the Restrepo hearing did not convene until June 10.124 The session proceeded well, as the GOP Senator voiced profound support and Restrepo comprehensively and candidly answered questions, while the committee members posing them appeared satisfied. His June 25, 2015 panel vote, however, was suspended for two weeks.125 The day of the hearing, Senator Grassley issued a prepared statement professing that the sessions for appellate choices in 2015 are practically identical to the standard established in 2007.126 He repeated the notions that Democrats reviewed

2015/05/13/pat-toomey-judge-restrepo_n_7277332.html (next week); Tamari, supra note 113 (next day).

121. 161 Cong. Rec. S2660 (daily ed. May 6, 2015) (statement of Sen. Reid); see also Tamari, supra note 113.

122. Ensuring an Informed Citizenry: Examining the Administration's Efforts to Improve Open Government: Hearing Before the S. Comm. on the Judiciary, 114th Cong. (May 6, 2015) (statement of Sen. Grassley, Chairman, S. Comm. on the Judiciary); accord supra notes 30-31 and accompanying text. But see supra Part II.A.4 (showing that the 2015 GOP record was not similar to Democrats' 2007 record).

123. Pat Toomey, I Am Not Delaying Judge L. Felipe Restrepo's 3rd Circuit Nomination, PITT. Post-GazeTTE (May 13, 2015, 12:00 AM), http://www.post-gazette.com/opinion/letters/2015/ 05/13/I-am-not-delaying-Judge-L-Felipe-Restrepo-s-3rd-Circuit-nomination/stories/201505130 068.

124. June 10 Nominations, supra note 27; see also 161 Cong. Rec. S2949 (daily ed. May 18, 2015) (statement of Sen. Reid) (reiterating criticism of GOP for delaying Restrepo and other nominees in committee and on floor); Tracie Mauriello, Toomey Signs Off on Nominee for Federal Appeals Court, PITT. PosT-GAZETTE (May 14, 2015, 8:12 PM), http://www.post-gazette.com/ local/region/2015/05/14/Toomey-signs-off-on-nominee-for-federal-appeals-court/stories/201 505140325; Spencer, supra note 113.

125. June 10 Nominations, supra note 27; see also 161 Cong. Rec. S2949 (daily ed. May 18, 2015) (statement of Sen. Reid); Mauriello, supra note 124; Spencer, supra note 113.

126. Grassley contended that the committee conducted hearings for the same number of nominees in 2007 and 2015. See July 9 Executive Business Meeting, supra note 42 (click embedded video to watch full meeting); June 10 Nominations, supra note 27; accord supra notes 30-31 and accompanying text. But see supra notes 33-36 and accompanying text. 
considerably more nominees in 2007, because the chamber at 2006's end returned many nominees whom President Bush re-nominated the following year under standard practice; however, Democrats violated tradition by approving numerous candidates over the 2014 lame duck session, which meant the number of 2007 and 2015 confirmations were basically the same. 127

Senators Reid and Leahy addressed Senator Grassley's contentions with applicable data on confirmations and hearings, which showed, for example, large discrepancies between 2007 and 2015 appointments.128 Thus, the Chair's assertions were less persuasive because he invoked statistics that relied on dissimilar yardsticks or assumptions that lacked factual supportideas exemplified by Grassley's claim that eleven 2015 appointments were somehow equivalent to forty 2007 confirmations. In any event, the biggest problem is that Republican Senators are not discharging their constitutional responsibility to fill judicial vacancies, even with the consensus nominees, many of whom GOP Senators propose or support.

Several factors left unclear when Restrepo might have final consideration. First, he needed a panel ballot. The committee made Stoll, the other appeals court nominee, however, wait six weeks after the hearing, but the Pennsylvania jurist only waited four. ${ }^{129}$ It was difficult to ascertain when Restrepo would secure a floor vote, due to the considerable time which the district court choices and Stoll needed in 2015 and because Senator McConnell had not clarified his June 4, 2015 mention of appellate court recommendations' ballots. ${ }^{130}$ For example, Texas and Utah re-nominees, who had powerful home-state politician support, waited three months between committee and final votes. 131 This is in stark contrast to Democrats' concerted efforts in helping appoint many judges during President Bush's last two years 132 and all well-qualified, centrist trial-level nominees before extended recesses. 133

The protracted delay of Restrepo lacked justification. President Obama initially designated the consensus jurist 14 months ago for a vacancy the U.S. Courts labeled an emergency, because of the numerous Third Circuit

127. July 9 Executive Business Meeting, supra note 42; accord supra notes 59-60 and accompanying text. But see supra note 63 and accompanying text (responding to Grassley's assertions).

128. See supra notes 33-36, 48-50, 65-66, 72 and accompanying text.

129. See July 9 Executive Business Meeting, supra note 42.

130. See supra notes 50-52, 98-103 and accompanying text.

131. See supra note 38 and accompanying text; see also Part II.A.4.

132. See supra notes 49,72 and accompanying text.

133. See supra note 49 and accompanying text. On December 9, the GOP agreed to a final vote on January 11, 2016. Jonathan Tamari, Senate Schedules Vote on Long-Delayed Pa. Nominee Restrepo, PHILA. InQUiReR (Dec. 9, 2015, 9:22 PM), http://www.philly.com/philly/blogs/capitol inq/Senate-schedules-vote-on-long-delayed-PA-nominee-Restrepo.html. 
appeals. 134 His prolonged wait contrasts to Stoll's, whom Obama nominated at the same time and who secured a March 11, 2015 hearing and April 23, 2015 Committee approval, 135 while the nominees who received the May 6 hearing were proposed the same day as Restrepo or later.136 None of the five designees underwent an earlier full investigation like Restrepo's, which leaves unclear why the panel canvass devoured six months, particularly when Restrepo had a thorough 2013 evaluation and was subsequently a district jurist.137 Senator Grassley's acknowledgement that he would conduct a hearing "when [he] get[s] the blue slips" and failure to mention a continuing inquiry undercut Senator Toomey's excuse for insisting on a half-year wait. 138 Observers also claimed that partisanship explained Republican slowing of nominees, as merely four district nominees received 2015 appointment in contrast to Democrats' approval of three circuit and 15 trial court judges by a similar point of Bush's tenure. 139

\section{The Implications of the 2015 Nomination AND CONFIRMATION PROCESSES}

This inaction means that the judiciary has nine appeals court, and 58 district, openings, while the U.S. Courts posit 32 circuit and trial court vacancies as emergencies, a figure that Republicans permitted to more than double over 2015.140 Empty posts hovered around 90 for much of the half decade following August 2009; circuit and district courts were only able to confront the rather low statistic of 68 vacancies after Democrats had exploded the nuclear option that prevented Republicans from successfully mounting filibusters. 141

134. See Judicial Emergencies, supra note 16.

135. See supra notes 102-103 and accompanying text.

136. Dale Drozd and LaShann Montique DeArcy Hall were first nominated on November 12, 2014, and Ann Donnelly was first nominated on November 20, 2014, while all three were renominated on January 7, 2015; Lawrence Vilardo was nominated on February 4, 2015. Judicial Confirmations for December 2015, U.S. CouRTs, http://www.uscourts.gov/judges-judgeships/ judicial-vacancies/archive-judicial-vacancies/2015/12/confirmations (last visited Dec. 4, 2015).

137. This shows the vetting did not start from scratch. Paul Gordon, Toomey's Explanation for Restrepo Delay Raises More Questions, Huffington Post (May 13, 2015, 1:37 PM), http://www. huffingtonpost.com/paulgordon/toomeys-explanation-for-restrepo-delay-raises-more-questions _b_7276448.html; Mauriello, supra note 117. But see Bendery, supra note 117 (quoting an aide saying that the panel "starts from scratch" on each new nominee).

138. After press scrutiny of Toomey, Grassley said the panel inquiry, not the blue slip, caused delay. Gordon, supra note 137; see also Bendery, supra note 117.

139. 161 ConG. REc. S3223 (daily ed. May 21, 2015) (statement of Sen. Leahy) (blaming the Republicans for the limited number of Senate confirmations); see also Bendery, supra note 117.

140. See supra notes 15-16 and accompanying text; see also Gary Fields \& John R. Emshwiller, Criminal Case Glut Impedes Civil Suits, WALl Street J. (Nov. 10, 2011), http://www.wsj.com/ articles/SB10001424052970204505304577001771159867642; Joe Palazzolo, In Federal Courts, the Civil Cases Pile Up, Wall Street J. (Apr. 6, 2015, 2:09 PM), http://www.wsj.com/articles/infederal-courts-civil-cases-pile-up-1428343746.

141. See supra note 45 and accompanying text. 
Delayed court appointments detrimentally affect the nominees, courts, and litigants. 142 They require capable, uncontroversial nominees to place lives and careers on hold and dissuade many impressive candidates from even thinking about serving on courts.143 Protracted review has also deprived tribunals of the judicial resources which they desperately need, impaired endeavors to speedily, inexpensively, and equitably resolve cases, 144 imposed extreme pressure on increasingly overburdened jurists, 145 and made litigants wait years on civil trials and settlements. 146 These deleterious consequences have also undermined citizen regard for both the process and the federal government's coordinate branches. 147 The lengthy executive appointments system has correspondingly denied the Obama Administration important upper-echelon officials whom it requires to efficiently operate the government. For instance, Lynch's prolonged analysis could have threatened national security and public safety. 148

\section{SUGGESTIONS FOR THE FUTURE}

The problematic selection phenomena recounted here clarify that the President and Senators must engage in meaningful cooperation at every phase of the nomination and confirmation processes to facilitate courts' delivery of justice. GOP officials and the leadership, especially Senators McConnell and

142. See June 10 Nominations, supra note 27; May 6 Nominations, supra note 41; Mar. 11 Nominations, supra note 27; Tobias, supra note 12, at 2253; see also sources cited supra note 36.

143. See Jennifer Bendery, Federal Judges Are Burned Out, Overworked and Wondering Where Congress Is, HufFingTON Post (Sept. 30, 2015, 2:15 PM), http://www.huffingtonpost.com/entry/ judge-federal-courts-vacancies_55d77721e4b0a40aa3aaf14b; Andrew Cohen, In Pennsylvania, the Human Costs of Judicial Confirmation Delays, ATLAnTic (Sept. 9, 2012), http://www.theatlantic. com/politics/archive/2012/09/in-pennsylvania-the-human-costs-of-judicial-confirmation-delays/ 261862; Everett \& Kim, supra note 14. On December 9, the GOP agreed to a final vote on January 11, 2016. John Tamari, Senate Schedules Vote on Long-Delayed PA Nominee Restrepo, PHILA. INQUIRER, Dec. 9, 2015. On December 15, the GOP finally agreed to set 2016 floor votes on four district nominees before the President's Day Recess. Two of these ironically are nominees for Iowa vacancies, who will be confirmed ahead of multiple nominees nominated before them in clear violation of regular order. 161 CoNG. REC. S8786 (daily ed. Dec. 17, 2015) (statement of Sen. Leahy).

143.

144. See Bernstein, Congress, supra note 94; sources cited supra notes 140, 143.

145. See, e.g., JOHN ROBERTS, 2010 YeAR-ENd REPORT ON THE FEDERAL JUdiciary 7-8 (2010), http://www.supremecourt.gov/publicinfo/year-end/2010year-endreport.pdf; Cohen, supra note 143.

146. Tobias, supra note 12, at 2253; see also sources cited supra notes $140,143$.

147. See sources cited supra notes 140, 143. The Attorney General has substantial responsibility for national security and public safety. For the idea that not or slowly confirming executive nominees can threaten national security, see Bernstein, Congress, supra note 94; Gabrielle Levy, Public Service Nominees Become Pawns in Political Squabbles, U.S. NEws \& WorLD REP. (Nov. 23, 2015, 6:53 PM), http://www.usnews.com/news/articles/2015/11/23/publicservice-nominees-become-pawns-in-political-squabbles.

148. See supra note 87 and accompanying text. 
Grassley, should not only continuously mouth the platitudes of regular order but also comply with it by at least employing the concepts deployed during President Bush's last years or instituting concrete mechanisms again that will effectively streamline nominations and confirmations, placing competent moderates in the numerous judicial and executive branch vacancies. 149

The White House ought to continue aggressively consulting Senators in jurisdictions where openings arise. These politicians should carefully augment collaboration by more promptly sending able, consensus prospects. 150 Merit selection panels, which evaluate, interview, and cautiously suggest applicants for Pennsylvania and Texas courts 151 have furnished useful assistance, but the commissions and officers whom they help frequently lack the requisite alacrity. 152 Thus, Senators could explore diverse, promising models, such as the California and Wisconsin panels that functioned successfully during a number of Bush years while recalibrating panel initiatives to expedite recommendations of candidates. ${ }^{153}$ For instance, the politicians should act more quickly when vacancies arise or diligently anticipate future empty posts. 154 Other valuable strategies include providing several candidates and ranking Senators' clear preferences, both of which enhance White House flexibility and obviate the necessity to reopen consideration when the administration disagrees with the lone individual mustered. 155

149. For many specific ideas, see Shenkman, supra note 51, at 298-311, and Tobias, supra note 12 , at 2255-66.

150. See supra Part II.A.1.

151. Jessica M. Karmasek, Members of Texas Judicial Evaluation Committee Announced, LEGAL NEwSLine (Apr. 17, 2013, 4:00 PM), http://legalnewsline.com/stories/510515096-members-oftexas-judicial-evaluation-committee-announced; Borys Krawczeniuk, Toomey, Casey Unveil Selection Process for Federal Judges, STANDARDSPEAKER.COM (Apr. 27, 2011), http://standardspeaker.com/

news/toomey-casey-unveil-selection-process-for-federal-judges-1.1138220; see also Western District Judgeships May Be Filled in 2015, PEnnsylvanians For Mod. CTS., http://pmconline.org/node/

1243 (last visited Nov. 2, 2015).

152. The two multi-year Texas Fifth Circuit vacancies and the many Texas district court vacancies could derive partly from the Texas Judicial Evaluation Commissions' slow pace. See supra Part II.A.1. The three Western District of Pennsylvania judgeships that lacked nominees for nearly two years may be partially attributable to the Pennsylvania Commissions' slow pace. Carl Tobias, Opinion, Pennsylvania's Missing Judges: Only Texas Has More Vacancies in Its Federal Judiciary, PITT. PosT-GAZETTE (May 8, 2015, 12:00 AM), http://www.postgazette.com/opinion/Op-Ed/

2015/05/08/Pennsylvania-s-missing-judges-Only-Texas-has-more-vacancies-in-its-federaljudiciary/

stories/201505080113; see also Current Judicial Vacancies, supra note 15.

153. Tobias, supra note 12 , at 2256.

154. Id.; see also supra note 22 and accompanying text.

155. GOP Senators more often send one then Democrats. See, e.g., Joseph Morton, Obama Nominates Omaha Attorney Rossiter to Federal Bench in Nebraska, OMAHA WoRLD-HeRALD (June 12, 2015, 12:15 AM), http://www.omaha.com/news/crime/obama-nominates-omaha-attorneyrossiter-to-federal-bench-in-nebraska/article_7517dc5c-1084-11e5-9f03-eb447e9aaa07.html. 
Should GOP lawmakers prove unresponsive to White House overtures by, for example, not proffering choices or moving too slowly, 156 the President could nominate without home-state politician support, which he rarely does. This practice is counterproductive and the blue slip policy can undercut its efficacy.157 The President might also apply rather drastic, controversial options. He could recommend candidates for all vacancies, which can dramatize and publicize how chronic openings acutely erode justice, strike compromises about the type of choices whom Obama prefers or invoke "trades," a measure on which the White House apparently capitalized on to fill six protracted Georgia vacancies. 158

The President should expedite the process before and when home-state politicians tender submissions. For instance, the White House could assign nominations higher priority or considerably greater resources.159 The President might correspondingly facilitate American Bar Association candidate assessments, Federal Bureau of Investigation background checks, and White House evaluations and nominations while urging speedy chamber analysis.160 Because most Obama nominees have been capable and uncontroversial, the President should enjoy a measure of flexibility in designating the type of choices whom he prefers during early 2016, as that has essentially been the custom at the commencement of the eighth year of Presidents' administrations-a phenomenon which the selection process in President Bush's tenure saliently illustrates. 161

The panel ought to convene additional hearings that encompass more nominees while carefully fostering swifter discussions and votes. 162 The committee might explore other productive ideas for expediting its review. One valuable notion, which Senator Hatch employed as Judiciary Chair during the

But see Tobias, supra note 12, at 2251 (affording examples of Democratic Senators who recommended one candidate).

156. See supra Part II.A.1.

157. This lacks efficacy because Republicans in states with vacancies can retain their blue slips and halt confirmation processes. See Goldman et al., supra note 12, at 16-18; Tobias, supra note 12 , at 2260-61.

158. Everett \& Kim, supra note 14; Daniel Malloy, The Delegation Georgians in D.C., ATLANTA J.Const., July 20, 2014, at 14A; Tobias, supra note 12, at 2261. The President may also nominate from a state in the circuit other than the one where a vacancy occurs, as nominating from a state where the opening arises is a custom, not a rule. See id. at 2251. But see 28 U.S.C. § 44(c) (2012) ("In each circuit (other than the Federal judicial circuit) there shall be at least one circuit judge in regular active service appointed from the residents of each state in that circuit." (footnote omitted)).

159. See Goldman et al., supra note 12, at 11-13; Tobias, supra note 12, at 2250-51.

160. A Federal Judicial Center study found that irreducible temporal restraints are inherent, given the many entities which now participate in selection. See Gordon Bermant et al., Judicial Vacancies: An Examination of the Problem and Possible Solutions, 14 Miss. CoLl. L. Rev. 319, 335 (1994); Tobias, supra note 12, at 2235.

161. See supra Parts I, II.A.1-4.

162. See supra Parts II.A.1-4. 
Bush Administration, was conducting truncated panel hearings for distinguished, mainstream nominees. 163 A more recent example of this device was the June 10, 2015 session for Restrepo and two district nominees, which comprised 45 minutes of pointed questions and candid, thorough responses. 164 Another concept that deserves assessment is eschewing routine delay of committee votes until the next meeting, particularly of nominees nominated to emergencies. 165

For his part, the Majority Leader needs to dramatically increase robust floor debates and ballots. For example, he must revisit a constructive practice applied during President Bush's tenure of granting chamber votes for all strong, uncontroversial district nominees on the Executive Calendar immediately before prolonged recesses, as Senator Leahy suggested.166 Senator McConnell also needs to explicitly illuminate his June comments on appellate nominees, because considering minuscule numbers of circuit nominees across the President's concluding years would be unprecedented. 167

Were Republican obstruction to continue, the President could apply more drastic notions. For instance, Obama may rely on the bully pulpit to carefully hold numerous GOP lawmakers accountable, take selection to the people or make vacant slots a presidential election issue.168 The Chief Executive and Senators could agree to dramatically change the process through inaugurating a bipartisan judiciary whereby Republicans tap some percentage of nominees, a regime which a few Senators, especially the Pennsylvanians, have adopted.169 Some of these ideas might be packaged with judgeship legislation, which becomes effective during 2017, so that neither party would capture advantage. 170

163. See Tobias, supra note 12 , at 2263.

164. See June 10 Nominations, supra note 27; see also supra notes $124-125$ and accompanying text.

165. See supra Part II.A.3. Restrepo deserved a first listing vote, but Grassley did hold him over. See supra note 125 and accompanying text.

166. See supra notes 51-53,109 and accompanying text.

167. He did manage to convene Stoll's "yes" or "no" vote for early July. See supra Part III.A.

168. All Presidents enjoy a measure of public respect for the high office they hold and may capitalize on that respect to promote initiatives, such as filling court vacancies, by going directly to the people. For example, Obama might publicly shame home state politicians who do not recommend candidates for vacancies. See David R. Stras \& Ryan W. Scott, Navigating the New Politics of Judicial Appointments, 102 Nw. U. L. REV. 1869, 1902-06 (2008); Tobias, supra note 12, at 2261.

169. Michael J. Gerhardt, Judicial Selection as War, 36 U.C. DAVIS L. REV. 667, 688 (2003); Carl W. Tobias, Postpartisan Federal Judicial Selection, 51 B.C. L. REV. 769, 790 (2010); see also supra notes 112, 114-116 and accompanying text. The Senator whose party does not occupy the White House suggests one of every four nominees. Western District Judgeships May Be Filled in 2015, supra note 151.

170. See generally Carl Tobias, Filling the D.C. Circuit Vacancies, 91 IND. L.J. 121 (2015) (analyzing judgeship legislation with a 2017 effective date, so neither party would realize advantage because the appointing President would not be known). 
Finally, selection participants may want to consider multiple ways of stopping or ameliorating the "confirmation wars." Ending or at least tempering the vicious cycle of paybacks and strident, counterproductive partisanship summarized by the majority's rhetoric and concomitant actions will be important. Particularly ironic about the GOP treatment of 2015 designees is the resemblance to numerous presidential election years, specifically that of Democratic President Bill Clinton. ${ }^{171}$

\section{CONCLUSION}

Professors Gerhardt and Stein and Professor Shugerman inform understanding of modern judicial selection partly by agreeing that confirmations in the early Republic (whether a Golden or Bronze Age) eclipsed the contemporary process.172 Partisanship, obstruction, and paybacks-formerly reserved for Supreme Court appointments-now drive modern selection, infecting processes for many appellate and even district court nominees. Professors Gerhardt and Stein admonish that politics has always influenced judicial selection but urge consideration of significant differences between the early and modern eras which have affected the confirmation process, including "issues, technology, the courts' dockets, the prestige of serving in the federal judiciary, and the times themselves." 173 Shugerman concomitantly prefers the early days' "open and honest partisan conflicts [to] our contemporary judicial politics of personal attacks masking those partisan conflicts." 174 The reality of the modern selection processfueled by obstruction, delay for delay's sake, and rampant dependence on procedural technicalities to stall nominees' consideration-imposes deleterious effects on federal judges, courts, and litigants.

Thus, many observers of the judicial and executive branch selection processes seem to agree that reinstating regular order would improve selection. However, if the meager 2015 appointments represent the new majority's definition of regular order, this leadership does not exactly inspire confidence. It is especially ironic that the regular order paean suffuses GOP discourse, even while Republicans continue to drastically undercut this order in the approval process. GOP obstruction, delay, and failure to respect its duty have undermined attempts by the coequal judicial and executive branches to rigorously discharge their constitutional responsibilities. Accordingly, President Obama, the chamber and Senators must directly institute again the regular order that the GOP vociferously champions, which is felicitously

171. Carl Tobias, Judicial Selection at the Clinton Administration's End, 19 LAW \& INEQ. 159, 179-81 (2001); see also, e.g., Carl Tobias, Dear President Bush: Leaving a Legacy on the Federal Bench, 42 U. Rich. L. Rev. 1041, 1041 (2008) (discussing how President Bush could fill judicial vacancies during his final year in office).

172. See supra notes 1-2 and accompanying text.

173. Gerhardt \& Stein, supra note 1, at 615.

174. Shugerman, supra note 2 , at 76. 
demonstrated by the normal appointments record during the last two Bush years. Both parties must at least eschew the blatant partisanship, obstruction, and paybacks, which could allow the Senate to realize a Bronze, if not Golden, Age of selection, ideas about which Professors Gerhardt, Stein, and Shugerman concur. Only then may federal judges better deliver justice and high-level executive officers insure the law's faithful effectuation. 